\title{
Defining normal IgG changes throughout pregnancy
}

\author{
Jena Abel,MD, ${ }^{1}$ Jona Conklin, MD, ${ }^{1}$ Stephen K. Hunter, MD, PhD, ${ }^{1}$ Ryan Empey, MD, ${ }^{1}$ \\ Eric Tyler, MD, ${ }^{1}$ Ashley Christensen, ${ }^{2}$ Katelyn Talcott, ${ }^{2}$ Zuhair K Ballas, MD, ${ }^{3}$ Mark \\ Santillan, $\mathrm{MD}^{1}$ Donna Santillan, $\mathrm{PhD}^{1}$
}

Keywords: Immunoglobulin G, pregnancy, first trimester, second trimester, third trimester

\section{Background:}

Immunoglobulin $G(\operatorname{lgG})$ is the major serum immunoglobulin, accounting for roughly $75 \%$ of all immunoglobulin. IgG is the only class of immunoglobulin that crosses the placenta and it serves as the main immunologic barrier between the fetus and external environments. There has not been a clear consensus on what the normal values of IgG are throughout pregnancy. The aim of this study is to measure serum immunoglobulin $G$ in each trimester of the pregnant female to determine a normal IgG profile throughout all trimesters in normal pregnancy.

${ }^{1}$ Department of Obstetrics and Gynecology, Carver College of Medicine, University of lowa Hospitals and Clinics, lowa City, IA, 52242

${ }^{2}$ Carver College of Medicine, University of lowa Hospitals and Clinics, lowa City, IA, 52242

${ }^{3}$ Department of Internal Medicine, University of lowa Hospitals and Clinics, lowa City, IA, 52242

\section{Methods:}

De-identified maternal blood samples were obtained from the Maternal Fetal tissue bank. The maternal plasma samples were obtained from 61 subjects within the Maternal Fetal tissue bank that had a sample in each trimester throughout their pregnancy. The determination of IgG in the maternal plasma samples was determined by colorimetric Enzyme-Linked Immunosorbent Assay (ELISA).

\section{Results:}

The mean values of IgG concentration in maternal plasma showed a significant drop throughout pregnancy. The mean IgG concentration in the first trimester was $18.5 \mathrm{mg} / \mathrm{ml} \pm 0.88$ and gradually declined to the second trimester mean concentration of $17.4 \mathrm{mg} / \mathrm{ml} \pm 0.86$. The mean IgG concentration at term was $16.5 \mathrm{mg} / \mathrm{ml} \pm 0.82$. It was determined that the term IgG concentration $(>37$ weeks) is $90 \%$ of the first trimester. Maternal age, body mass index, infant birth weight, and infant Apgars were not

Please cite this paper as: Abel J, Conklin J, Hunter S, Empey R, Tyler E, Christensen A, Talcott K, Ballas Z, Santillan M, Santillan D. Defining normal IgG changes throughout pregnancy. Proc Obstet Gynecol. 2013 ;3(2):Article 8 [ 2 p.]. Available from: http://ir.uiowa.edu/pog/. Free full text article.

Corresponding author: Donna Santillan, Department of Obstetrics and Gynecology, University of lowa, 463 MRF, 200 Hawkins Drive, lowa City, IA 42242. donna-santillan@uiowa.edu

This is an Open Access article distributed under the terms of the Creative Commons Attribution 3.0 Unported License (http://creativecommons.org/licenses/by/3.0), which permits unrestricted use, distribution, and reproduction in any medium, provided the original work is properly cited. 
related to the extent of decrease of immunoglobulin $\mathrm{G}$ during pregnancy.

\section{Conclusion:}

While previous studies have revealed contradictory findings regarding the concentration of $\operatorname{lgG}$ in pregnancy and its trend we have found a statistically significant drop in $\operatorname{lgG}$ throughout pregnancy with the lowest being at term. Our study determined that normal values of IgG in pregnancy ranged from a mean in the first trimester of $18.5 \mathrm{mg} / \mathrm{ml}$ to $16.5 \mathrm{mg} / \mathrm{ml}$ at term. 